\title{
MRI tracing of ultrasmall superparamagnetic iron oxide nanoparticle-labeled endothelial progenitor cells for repairing atherosclerotic vessels in rabbits
}

\author{
HONGXIA WEI ${ }^{1}$, TINGTING TAN ${ }^{1}$, LI CHENG $^{1}$, JIAPENG LIU ${ }^{2}$, HONGYAN SONG $^{1}$, LEI LI $^{1}$ and KUI ZHANG ${ }^{1}$ \\ ${ }^{1}$ Department of Laboratory Medicine, The Affiliated Drum Tower Hospital of Nanjing University Medical School, \\ Nanjing Drum Tower Hospital, Nanjing, Jiangsu 210008; ${ }^{2}$ Department of Medical Imaging, \\ Shanghai Jiahui International Hospital, Shanghai 200233, P.R. China
}

Received July 17, 2019; Accepted March 30, 2020

DOI: $10.3892 / \mathrm{mmr} .2020 .11431$

\begin{abstract}
Endothelial progenitor cells (EPCs) have been discovered to be relevant to the prognosis of cardiovascular diseases. Previous research has demonstrated that EPCs serve vital roles in the occurrence and development of atherosclerosis. Significant improvements have been made in MRI technology and in the experimental use of EPCs for therapeutic angiogenesis and vascular repair. Nevertheless, the migratory, adhesive, proliferative and angiogenic properties of EPCs remain unknown. The aims of the present study were to investigate the potential of using non-invasive monitoring with ultrasmall superparamagnetic iron oxide nanoparticle (USPION)-labeled endothelial progenitor cells (EPCs) after transplantation, and to assess the treatment outcomes in an atherosclerotic rabbit model. EPCs derived from rabbit peripheral blood samples were labeled with USPION-poly-l-lysine (USPION-PLL). The morphology, proliferation, adhesive ability and labeling efficiency of the EPCs were determined by optical and electron microscopy. Moreover, biological activity was assessed by flow cytometry. In addition, T2-weighted image fast spin-echo MRI was used to detect cell labeling. USPION content in the labeled EPCs was determined by Prussian blue staining and scanning electron microscopy. Rabbit atherosclerosis model was established using a high-fat diet. USPION-labeled EPCs were transplanted into rabbits,
\end{abstract}

Correspondence to: Dr Kui Zhang, Department of Laboratory Medicine, The Affiliated Drum Tower Hospital of Nanjing University Medical School, Nanjing Drum Tower Hospital, 321 Zhongshan Road, Nanjing, Jiangsu 210008, P.R. China

E-mail: 15951946345@163.com

Abbreviations: USPION, ultrasmall superparamagnetic iron oxide nanoparticle; EPCs, endothelial progenitor cells; USPION-PLL, USPION-poly-l-lysine; SPIO, superparamagnetic iron oxide; T2WI, $\mathrm{T} 2$ weighted image

Key words: USPION, EPCs, atherosclerosis, cell transplantation, MRI and in vivo MRI was performed 1 and 7 days after transplantation. It was found that EPCs cultured on Matrigel formed capillary-like structures, and expressed the surface markers CD133, CD31, CD34 and vascular endothelial growth factor receptor 2 (VEGFR2). The optimal USPION concentration was $32 \mu \mathrm{g} / \mathrm{ml}$, as determined by adhesion and proliferation assays. It was identified that USPION-PLL nanoparticles were $10-20 \mathrm{~nm}$ in diameter. Histopathological analysis results indicated that 1 day after transplantation of the labeled EPCs, blue-stained granules were observed in the intima of vascular lesions in rabbit models after Prussian blue staining. Therefore, the present results suggest that USPION-labeled EPCs may play a role in repairing endothelial injury and preventing atherosclerosis in vivo.

\section{Introduction}

Atherosclerosis is characterized by atherosclerotic plaques that result from inflammatory cell infiltration, lipid peroxidation, extracellular matrix deposition and other factors (1). Moreover, atherosclerosis remains a major cause of long-term morbidity and mortality worldwide as it is a prerequisite to a large number of cardiovascular diseases (CVDs) (2); for example, the prevalence of CVDs was predicted to reach $43.9 \%$ in the United States in 2030 (3), and in 2015 alone, 17.7 million people died from CVD worldwide (4).While a coronary artery bypass graft is widely performed for the revascularization of occluded vessels, it cannot be used to treat the damage caused by atherosclerosis (5).

Endothelial cell dysfunction is considered the main cause of atherosclerosis (6). Endothelial cell dysfunction is a complex process initiated by phenotypic changes in endothelial cells that allows for the permeation of lipoproteins into subendothelial cells, as well as their physicochemical modification and trapping by macrophages, which ultimately become the foam cells that constitute the highly-thrombotic necrotic core of atherosclerosis plaque (7-9). Normal endothelial structure and function are important for maintaining vascular homeostasis. Moreover, a central feature of endothelial cell dysfunction is a reduced bioavailability of nitric oxide, which leads to abnormal physiological responses of the endothelial cells to 
stimuli, altered metabolism, oxidative stress and damage, and the recruitment of immune cells that accelerate atherosclerosis (8-10). Alterations in hemodynamics, immune responses and interventional therapy may also result in endothelial damage, dysfunction or death. Furthermore, risk factors for atherosclerosis, such as hypertension, alcoholism, smoking and diabetes, alter the function of endothelial cells (11).

Endothelial progenitor cells (EPCs) are relevant to the prognosis of cardiovascular diseases. Previous research has shown that EPCs play a vital role in the occurrence and development of atherosclerosis (12). Clinical trials and experimental studies have suggested that EPCs can form functional blood vessels in vivo (13-15), thus providing important cellular resources for the therapy of cardiovascular diseases via their direct involvement in angiogenesis and secretion of protective paracrine factors (16-19). EPC transplantation has also achieved positive results in the treatment of acute lung injury (20), cerebral ischemia (21), acute renal ischemia-reperfusion injury (22) and aneurysm (23) in animal models, suggesting that EPCs may have a clinical application in atherosclerosis.

Cell transplantation is one of the most widely studied biological approaches for improving atherosclerosis and other vascular diseases, with good clinical application prospects (24). Previous studies have shown that vascular endothelial repair is achieved via the migration and proliferation of adjacent endothelial cells (25-27). Moreover, Asahara et al (28) found that EPCs are bone marrow-derived CD $34^{+}$cells, which can differentiate and proliferate into mature endothelial cells, thus constituting an essential part of the vascular system. Atherosclerosis is a disease caused by an imbalance between vascular endothelial injury and repair (29). Previous studies have revealed that the bone marrow, vascular wall, adipose tissue, spleen, liver and intestine can release EPCs (30-32). Furthermore, EPCs can be specifically targeted to the site of endothelial injury, participate in the repair of damaged vascular endothelium and promote angiogenesis in ischemic tissues (33). However, transplantation of autologous EPCs still has several limitations, including a limited supply of expanded EPCs, impaired function, activity of transplanted cells and low survival rate of transplanted cells in an ischemic host environment $(34,35)$. In addition, EPCs in the bone marrow, peripheral blood and umbilical cord blood are highly immunogenic and can cause rejection (36-38). Currently, EPCs can only be used for autologous transplantation $(39,40)$. Furthermore, factors such as coronary heart disease, hypertension, diabetes mellitus, emphysema, acute lung injury, hyperlipidemia, liver fibrosis, systemic sclerosis, old age and long-term smoking, can decrease the number and function of autologous EPCs, which results in a reduced proportion of injected cells that successfully accumulate at the sites of vascular damage (41). Therefore, it is important to develop novel pro-angiogenic strategies to improve the efficacy of EPC transplantation.

Ultrasmall superparamagnetic iron oxide nanoparticles (USPIONs) with diameters $<50 \mathrm{~nm}$ have an iron oxide core that is stabilized by a monomer or polymer coating (42-44). USPIONs possess a highly reactive surface, uniform particle size distribution, beneficial suspension properties and the possibility of additional coating modification by conjugation with a drug (42-44). Moreover, USPIONs are being developed for cell processing (45), automated DNA extraction (46), detection of pathogens (47), drug delivery and neuroimaging. In addition, USPIONs are also being developed for imaging of tumors and metastases in the liver, spleen and bone marrow, and perfusion imaging of atherosclerotic plaques and thrombosis $(42,43,48-50)$.

While MRI technology, EPC-mediated therapeutic angiogenesis and vascular repair have advanced, the mechanisms of migration, adhesion, proliferation and angiogenic properties of EPCs remain unknown. Thus, identifying materials for the labeling of live cells is important for target tracing of living cells and promotion of tissue angiogenesis. To the best of our knowledge, no previous studies have examined USPION labeling of rabbit EPCs by MRI. Therefore, in the present study, labeled EPCs were transplanted into a rabbit arteriosclerosis model, and MRI was used to assess the effect of EPC transplantation and to examine the application of nanoparticles in vivo.

\section{Materials and methods}

Cell culture. Rabbit EPCs were extracted according to a previous report (51) using 40 rabbits (age, 2-3 months; sex, 20 males and 20 females; weight, 2.0-2.5 kg; Model Animal Research Center of Nanjing University). After mixing $5 \mathrm{ml}$ rabbit anti-coagulated whole blood with sterile PBS (1:1 ratio), $5 \mathrm{ml}$ rabbit lymphocyte separation medium (Tianjin HaoYang Biological Manufacture, Co., Ltd.) was added to $5 \mathrm{ml}$ of the above mixture (1:1 ratio). Density gradient centrifugation was performed at $367 \mathrm{x}$ g for $20 \mathrm{~min}$ at room temperature. The intermediate albuginea layer was extracted and washed with PBS three times, and the M199 medium (Prospec-Tany Techno Gene Ltd.) was added to count the suspended cells. Mononuclear cells at $5 \times 10^{6} / \mathrm{ml}$ were seeded on human fibronectin-coated ( $5 \mathrm{~g} / \mathrm{cm}^{2}$; BD Biosciences) culture dishes. EPCs were cultured in M199 culture medium containing $20 \%$ fetal calf serum (FCS; Gibco; Thermo Fisher Scientific, Inc.), $8 \mathrm{ng} / \mathrm{ml}$ vascular endothelial growth factor (VEGF; Prospec-Tany Techno Gene Ltd.) and $8 \mathrm{ng} / \mathrm{ml}$ basic fibroblast growth factor (bFGF; Prospec-Tany Techno Gene Ltd.) at $37^{\circ} \mathrm{C}$ with $5 \% \mathrm{CO}_{2}$. After $48 \mathrm{~h}$, non-adherent cells were removed, and the culture medium was changed every day to assess the morphology of the cells.

Flow cytometry. On the 10th day of culture, adherent cells were collected and adjusted to $1 \times 10^{6} / \mathrm{ml}$ with PBS. The proportions of cells positive for CD133, CD31, CD34 and vascular endothelial growth factor receptor 2 (VEGFR2) were determined by flow cytometry. Briefly, the cells were blocked with rabbit serum (cat. no. SL034; Beijing Solarbio Science \& Technology Co., Ltd.) at $37^{\circ} \mathrm{C}$ for $30 \mathrm{~min}$. Cells were washed with PBS and incubated with FITC-CD34 (1:100; cat. no. bs-0646R-FITC; BIOSS), PE-CD133 (1:100; cat. no. bs-0395R-PE; Beijing Biosynthesis Biotechnology, Co., Ltd.), FITC-CD31 (1:100; cat. no. bs-0195R-FITC; Beijing Biosynthesis Biotechnology, Co., Ltd.) and PE-VEGF receptor 2 (1:100; cat. no. bs-10412R-PE; Beijing Biosynthesis Biotechnology, Co., Ltd.) primary antibodies at $4^{\circ} \mathrm{C}$ for $20 \mathrm{~min}$.

Rabbit auricular whole blood $(1 \mathrm{ml})$ was collected and mixed with $2 \mathrm{ml}$ erythrocyte lysate (BD Biosciences). The mixture was placed at room temperature for $5 \mathrm{~min}$ and 
centrifuged at $367 \mathrm{x}$ g for $20 \mathrm{~min}$ at room temperature. After discarding the supernatant, the cell pellets were adjusted to $1 \times 10^{6} / \mathrm{ml}$ with PBS. CD $34^{+}$and $\mathrm{VEGFR}^{+}$circulating EPCs were detected by flow cytometry. An isotype-matched antibody (1:100; cat. no. bs-0295R-FITC; Beijing Biosynthesis Biotechnology, Co., Ltd.) was used as the control. Samples were analyzed on a fluorescence-activated cell sorting instrument (FACSCalibur; BD Biosciences) and Cell Quest v6.0.1 software (BD Biosciences).

Angiogenesis. Matrigel (BD Biosciences; $500 \mu \mathrm{l}$ ) was added into $4 \mathrm{ml} \mathrm{M199}$ medium. Adherent cells at $1 \times 10^{6} / \mathrm{ml}$ were collected and seeded on Matrigel-coated plates. After incubation at $37^{\circ} \mathrm{C}$ for 24,48 and $72 \mathrm{~h}$, angiogenesis was observed under a light microscope (magnification, x20; Carl Zeiss AG).

Cell labeling with USPION and PLL. Polylysine (PLL; $0.5 \mathrm{ml}$; Sangon Biotech Co., Ltd.) was diluted 10 times with sterilized water. USPIONs (Taiwan Advanced Nanotech, Inc.; $0.2 \mathrm{ml}$ ) were prepared at a final concentration of $1 \mu \mathrm{g} / \mu \mathrm{l}$. The diameters of the USPION particles and USPION particles conjugated with PLL (USPION-PLL) were measured by scanning electron microscopy (magnification, $x 40$; JSM-7800 Prime; JEOL, Ltd.).

USPION concentrations for labeling were $0,1,2,4,8$, 16, 32, 64, 128 and $256 \mu \mathrm{g} / \mathrm{ml}$. Sterile cover slides (diameter, $115 \mathrm{~mm}$ ) were placed in 24-well culture plates (Corning, Inc.). After $12 \mathrm{~h}$ of incubation at $37^{\circ} \mathrm{C}$ of different USPION concentrations with $2 \times 10^{7} / \mathrm{ml}$ EPCs in 24 -well culture plates, the unlabeled USPIONs were removed by washing three times with PBS. Then, M199 medium supplemented with $20 \%$ FCS was added, and the cells were cultured at $37^{\circ} \mathrm{C}$ for $12 \mathrm{~h}$. Cells in the control group were cultured in M199 medium at $37^{\circ} \mathrm{C}$ for $12 \mathrm{~h}$. Cells were incubated with $0.4 \%$ Trypan blue for 2-3 $\mathrm{min}$ at room temperature to detect the activity of labeled cells and determine the optimal USPION concentration. Cover slides placed in the dish were stained with Prussian blue (40 g/l; cat. no. BP-DL122; Nanjing SenBeiJia Biological Technology Co., Ltd.) for $30 \mathrm{~min}$ at room temperature primarily, and then another $15 \mathrm{~min}$ for secondary staining. Labeling efficiency was observed under a confocal microscope (magnification, x20; Carl ZeissAG) with image acquisition.

Cell viability. An MTT assay was used to assess the proliferative activity of EPCs after labeling. A total of $1 \times 10^{5}$ EPCs per well were seeded into 96-well plates. Then, 6-wells in the optimal labeling concentration and unlabeled groups were assessed at 1, 2, 3, 4, 5, 6 and 7 days. After incubation with $20 \mu \mathrm{l}$ MTT solution at $37^{\circ} \mathrm{C}$ (Nanjing KeyGen Biotech Co., Ltd.; $5 \mathrm{~g} / \mathrm{l}$ ) for $4 \mathrm{~h}$, the culture medium was discarded and $100 \mu \mathrm{l}$ DMSO was added into each well. Formazan crystals were dissolved by shaking for $10 \mathrm{~min}$. Absorption was measured on a microplate reader at $490 \mathrm{~nm}$ (Bio-Rad Laboratories, Inc.).

Cell adhesion. Adherent labeled EPCs cultured for 3 days were collected and suspended in M199 medium. Then, 500 cells/well were added into 24 -well plates. Adherent cells were cultured in M199 medium containing 20\% FCS $(0.5 \mathrm{ml})$ in an incubator with $5 \% \mathrm{CO}_{2}$ at $37^{\circ} \mathrm{C}$ for $1 \mathrm{~h}$. In total, 20 visual fields were randomly selected for cell counting using a light microscope (magnification, x20).

Scanning electron microscopy. EPCs were labeled with USPIONs at the optimal labeling concentration for $24 \mathrm{~h}$ and fixed with $2.5 \%$ neutral glutaraldehyde solution. Scissors was used to remove 1-3 muscle blocks with a cross-section of $\sim 1 \times 1 \mathrm{~mm}$. Extracted muscle blocks were attached to glass slides to make them stretch. The slides were then fixed with $2.5 \%$ neutral glutaraldehyde solution $(10 \mathrm{ml} 25 \%$ glutaraldehyde solution; $50 \mathrm{ml} 0.2 \mathrm{M}$ phosphate buffer; $40 \mathrm{ml}$ distilled water) at $4^{\circ} \mathrm{C}$ for $>15 \mathrm{~min}$. Electron microscopy was performed using a JSM-7800 Prime microscope (magnification, x200; JEOL, Ltd.). Elemental analysis of labeled cells was performed on an energy dispersive spectrometer (JEOL, Ltd.). Data were analyzed using the Gatan Microscopy Suite software version 2.11 (Gatan, Inc.; Thermo Fisher Scientific, Inc.).

MRI. Labeled cells $\left(2 \times 10^{6}\right)$ in the experimental and control groups were collected and diluted in $0.5 \%$ agarose to $1 \times 10^{6}$ cells $/ \mathrm{ml}$. T2 map scanning was performed by MRI (1.5 T; Philips Medical Systems B.V) with an 8-channel head circular. The imaging parameters were: Field-of-view (FOV), $9.0 \mathrm{~mm}$; echo time (TE), 105-1,500 ms; repetition time (TR), 2,300 ms; echo number, 32 and number of signals averaged $(\mathrm{NSA})=1$. The final $\mathrm{T} 2$ value was the average of three central $\mathrm{T} 2$ values in each test tube.

Atherosclerosis rabbit model. In total, 40 rabbits (Model Animal Research Center of Nanjing University; age, 2-3 months; sex, 20 males and 20 females; weight, 2.0-2.5 kg) were divided into the model and control groups, with 20 animals per group. The animals were housed at $20-25^{\circ} \mathrm{C}$ and 40-60\% humidity, under a 12-h light/dark cycle, with free access to food and water. The rabbits in the model and control groups were fed high-fat (18\% extra fat vs. the standard diet) and standard diets for 12 weeks, respectively. In the 6th and 12th weeks, $2 \mathrm{ml}$ rabbit auricular venous blood was collected from the ear margin vein and placed at room temperature for $30 \mathrm{~min}$. Blood was sampled from an ear margin vein. Serum was extracted by centrifugation at $200 \mathrm{x} \mathrm{g}$ for $10 \mathrm{~min}$ at $4^{\circ} \mathrm{C}$ for the measurement of total cholesterol (TC; cat no. RJ21458), triglycerides (TG; cat. no. RJ21057), low-density lipoproteins (LDL; cat. no. RJ21040) and high-density lipoproteins (HDL; cat. no. RJ21068) using ELISAs (Shanghai Renjie Biotechnology Co., Ltd.).

After 12 weeks, the model and control groups were anesthetized by intramuscular injection with $5 \mathrm{mg} / \mathrm{kg}$ Lumianning (China Animal Husbandry Animal Health Products Co., Ltd.) and an intravenous injection of $15 \mathrm{mg} / \mathrm{kg}$ propofol and scanned using CT and MRI with the animals in the supine position. Vascular lesions were located based on CT scan results. The vessels in the lesion area were separated in the model group. The rabbits were euthanized by intramuscular injection with $16 \mathrm{mg} / \mathrm{kg}$ Lumianning and intravenous injection with $80 \mathrm{mg} / \mathrm{kg}$ propofol; the rabbits died immediately due to cardiac blood conduction and respiratory inhibition, and the death was painless as xylazine (one of the main ingredients of Lumianning alongside dihydroetorphine hydrochloride) is an anesthetic (52-56). In the control group, the vessels in 
the corresponding area were fixed with $3 \%$ formaldehyde at $4^{\circ} \mathrm{C}$ for $24 \mathrm{~h}$, embedded in paraffin and sectioned into $5-\mu \mathrm{m}$ sections. Hematoxylin and eosin (H\&E) staining was subsequently performed and stained cells were visualized using a light microscope (magnification, $x 20$ ). The sections were stained with $0.2 \%$ hematoxylin for 3-8 min at room temperature and then stained with $0.5 \mathrm{~g} / 100 \mathrm{ml}$ eosin for 1-3 min at room temperature.

Immunohistochemistry was then performed. The sections were prepared as above and were blocked with 5\% goat serum (cat. no. 0060-01; SouthernBiotech) for $10 \mathrm{~min}$ at room temperature. Subsequently, the sections were incubated with the following primary antibodies for $2 \mathrm{~h}$ at room temperature: Anti-CD280 (1:100; cat. no. b-6412R; Beijing Biosynthesis Biotechnology Co., Ltd.) and anti-matrix metalloproteinase (MMP)-2 (1:200; cat. no. b-0412R; Beijing Biosynthesis Biotechnology Co., Ltd.). Following the primary antibody incubation, the sections were incubated with a horseradish peroxidase-conjugated goat anti-rabbit IgG secondary antibody (1:3,000; cat. no. bs-10295-g-HRP; Beijing Biosynthesis Biotechnology Co., Ltd.) for $30 \mathrm{~min}$ at room temperature. The morphological changes of the vessels were observed using light microscopy (magnification, $\mathrm{x} 400$ ). The study was approved by the Animal Care and Use Committee of The Affiliated Drum Tower Hospital of Nanjing University Medical School, Nanjing Drum Tower Hospital.

Cell transplantation. In the transplantation group, 10 rabbits were injected with $1 \times 10^{7}$ labeled EPCs into the injured arterial lumen with a $1 \mathrm{ml}$ syringe. In the control group, 10 rabbits were injected with unlabeled EPCs. Then, 1, 7 and 16 days after cell transplantation, the rabbits were scanned in the supine position on a $1.5 \mathrm{~T}$ MRI with head and neck phased-array coils. The imaging sequences were: $\mathrm{T} 2$ weighted image (T2WI) spin-echo sequence, $\mathrm{TR}=2,300 \mathrm{~ms}$; $\mathrm{TE}=120.0 \mathrm{~ms}$ and $\mathrm{FOV}=9.0 \mathrm{~mm}$. Local signal intensity was observed in the control and transplantation groups.

Then, 1, 7 and 16 days after transplantation, 1 rabbit per group was sacrificed after MRI scanning as previously described. The atherosclerotic artery $(3 \mathrm{~cm})$ was separated, fixed with $10 \%$ formaldehyde at $4^{\circ} \mathrm{C}$ for $24 \mathrm{~h}$ and embedded in paraffin. After transverse sectioning $(5 \mu \mathrm{m})$ of the blood vessel, it was fixed at room temperature with $3 \%$ paraformaldehyde for $30 \mathrm{~min}$, washed with PBS three times and stained with Prussian blue $(40 \mathrm{~g} / \mathrm{l})$ at room temperature for $30 \mathrm{~min}$. The effect of labeled cell transplantation was observed under a confocal microscope (magnification, x20; Carl Zeiss AG).

Statistical analysis. Data were analyzed using SPSS 17.0 (IBM Corp). Measurement data are presented as the mean \pm SD. A comparison of group means was performed using an unpaired Student's t-test. $\mathrm{P}<0.05$ was considered to indicate statistically significant difference.

\section{Results}

Characteristics of the EPCs. It was found that EPCs cultured in fibronectin-coated plates in culture medium changed from a globe-like shaped cells to a thin structure, with some cells acquiring a fusiform pebble-like shape at day 10 (Fig. 1A).
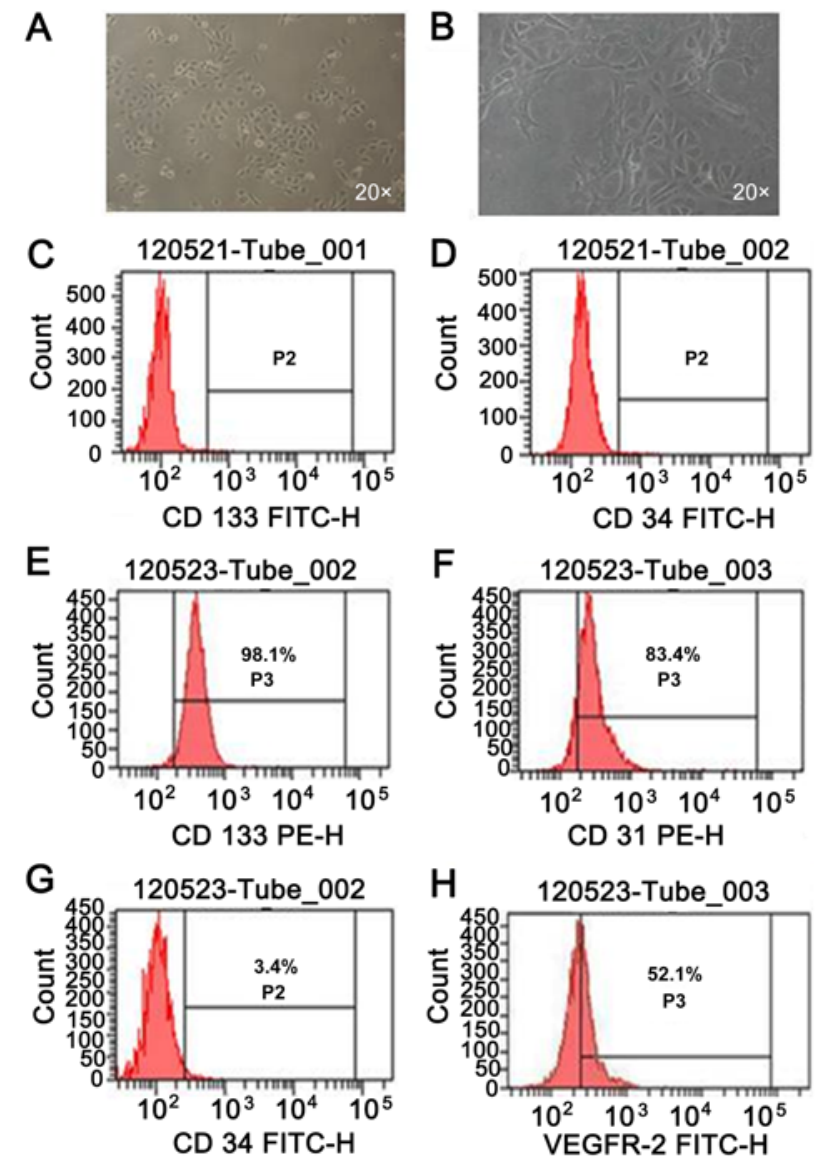

Figure 1. Morphological characteristics of rabbit EPCs. (A) Cells changed from a globe-like shape to a thin structure, with acquiring a fusiform pebble-like shape at day 10. Magnification, x20. (B) EPCs formed a capillary-like structure after $48 \mathrm{~h}$ on Matrigel. Magnification, x 20 . (C-H) Expression levels in EPCs of the endothelial cells surface markers (C and E) CD133, (D and G) CD34, (F) CD31 and (H) VEGFR2 were 98.1, $3.4,83.4$ and $52.1 \%$, respectively. EPCs, endothelial progenitor cells; FACS, fluorescence-activated cell sorting; VEGFR-2, vascular endothelial growth factor receptor 2 .

Furthermore, a Matrigel model was used to investigate whether cultured cells could be induced to form capillary-like structures in vitro. The present results suggested that EPCs could form a capillary-like structure after $48 \mathrm{~h}$ (Fig. 1B). Moreover, flow cytometry of EPCs demonstrated that the expression levels of the EPC surface markers CD133 (Fig. 1C and E), CD31 (Fig. 1F and H), CD34 (Fig. 1D and G) and VEGFR2 (Fig. 1H) were 98.1, 83.4, 3.4 and $52.1 \%$, respectively. These results were consistent with those of surface markers in mature endothelial cells $(57,58)$.

USPION-labeled EPCs retain adhesion and proliferative abilities. To examine cell proliferation and viability of EPCs labeled with different USPION concentrations, an MTT assay was performed. It was demonstrated that cell viability decreased with increasing USPION labeling time and concentration. While no significant differences were found in absorbance (490 $\mathrm{nm}$ ) values among the 1, 2, 4, 8 and $16 \mu \mathrm{g} / \mathrm{ml}$ groups (Fig. 2A), cell proliferation and viability were suppressed in the $64,128,256$ and $512 \mu \mathrm{g} / \mathrm{ml}$ groups. It was also found that the optimal USPION concentration was $32 \mu \mathrm{g} / \mathrm{ml}$, with a cell viability of $78.3 \pm 12.2 \%$ ( $\mathrm{P}<0.05$ vs. $64 \mu \mathrm{g} / \mathrm{ml}$ group; 


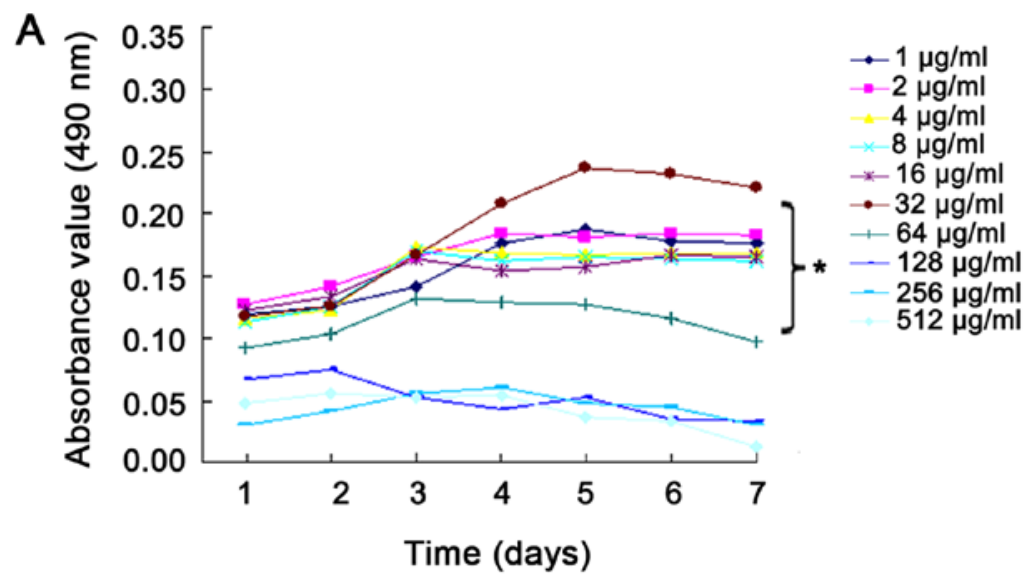

B

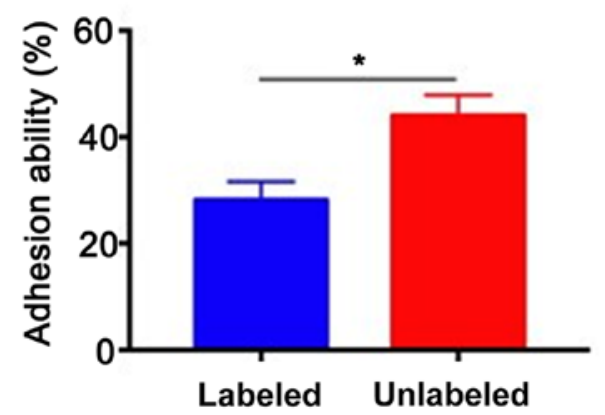

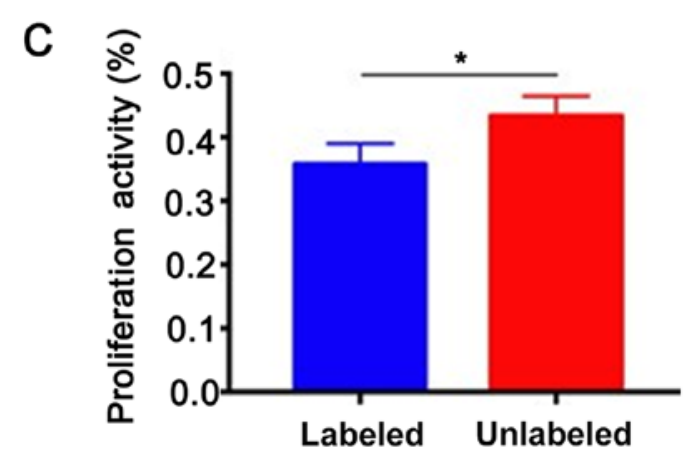

Figure 2. Cell viability upon labeling. (A) Endothelial progenitor cell viability was analyzed by MTT assay. Cell growth and viability were suppressed in the $64,128,256$ and $512 \mu \mathrm{g} / \mathrm{ml}$ groups. The optimal ultrasmall superparamagnetic iron oxide nanoparticle concentration was $32 \mu \mathrm{g} / \mathrm{ml}$, with cell viability of $78.3 \pm 12.2 \%$. (B) Adhesive ability. (C) Proliferative activity. ${ }^{*} \mathrm{P}<0.05$.

Fig. 2A). The adhesion rate of EPCs in the labeled group was only $28.16 \pm 3.45 \%$ at $1 \mathrm{~h}$ after passage with $32 \mu \mathrm{g} / \mathrm{ml}$ USPION, which was much lower compared with the unlabeled group $(53.98 \pm 3.71 \%$; $\mathrm{P}<0.05)$. The present results suggested that the proliferative ability of EPCs in model rabbits was significantly lower compared with the control group (0.588 \pm 0.032 vs. $0.644 \pm 0.031 ; \mathrm{P}<0.05$; Fig. $2 \mathrm{~B}$ and $\mathrm{C}$ ).

Labeling of EPCs is successful. The prevalence of USPION content in the labeled EPCs was demonstrated by Prussian blue staining and scanning electron microscopy. Prussian blue staining identified blue iron particles in the cytoplasm of labeled EPCs at a $32 \mu \mathrm{g} / \mathrm{ml}$ USPION labeling (Fig. 3A), while no blue iron particles were found in the unlabeled EPCs (Fig. 3B). Scanning electron microscopy results indicated that USPION-PLLs were uniform in size and 10-20 nm in diameter (Fig. 3C and D). After labeling of EPCs, it was found that USPIONs were irregularly distributed in the cytoplasm and uniform in size, and no nanoparticles were found in the nucleus (Fig. 3E). Energy spectrum element analysis results suggested that USPION-PLL nanoparticles were mainly composed of iron (Fig. 3F), but no iron was found in the labeled cells after 3 days of culture (Fig. 3G). In vitro MRI results indicated that the T2WI signal intensity of USPION-labeled EPCs decreased with increasing USPION concentration compared with unlabeled cells. However, the T2WI signal intensity of $32 \mu \mathrm{g} / \mathrm{ml}$ USPION-labeled EPCs showed relatively good signals compared with the other groups (Fig. 3H and I), suggesting successful labeling of EPCs with USPIONs.
Success of the atherosclerotic rabbit model. Serum TC, LDL and HDL levels in rabbits fed high-fat diet were increased significantly at 12 weeks $(\mathrm{P}<0.01$; Fig. 4A-D). CT images showed that the blood vessel wall in the control group was smooth and intact with no abnormal phenotypes, such as protuberances in the vessel lumen. However, atherosclerotic plaques attached to the aortic wall were found in the modeling group, which were protruding into the vascular lumen (Fig. 4E and F). $\mathrm{H} \& \mathrm{E}$ staining results demonstrated that the vascular endothelium in the control group was intact with uniformly distributed elastic fibers. Moreover, no foam cell or lipid deposition was observed under light microscopy in the control group. However, obvious intimal hyperplasia and irregular arterial lumen were observed in the model group, with lipid plaques intruded into the lumen and a large number of foam cells aggregated in the plaques (Fig. $4 \mathrm{G}$ and $\mathrm{H}$ ). Compared with the control group, matrix metalloproteinase- 2 expression was positive in the atherosclerotic plaques of the modeling group, mainly in the cytoplasm of foam cells and endothelial cells in the plaques (Fig. 4I and J). In addition, positive expression of CD280 was also observed in the foam cells of atherosclerotic plaques in the modeling group (Fig. 4K and L). Collectively, the present results indicated the successful establishment of the atherosclerotic rabbit model in this study.

Transplantation of USPION-labeled EPCs promotes atherosclerosis repair. Compared with the control group, the injured vessels in the model group showed no significant difference in contralateral vessels after the transplantation of USPION-labeled EPCs. Moreover, there were low signals in the 


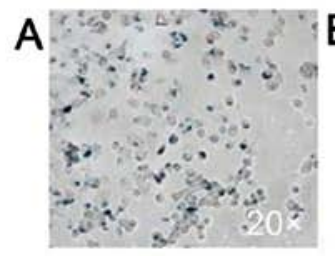

F Full scale counts:472

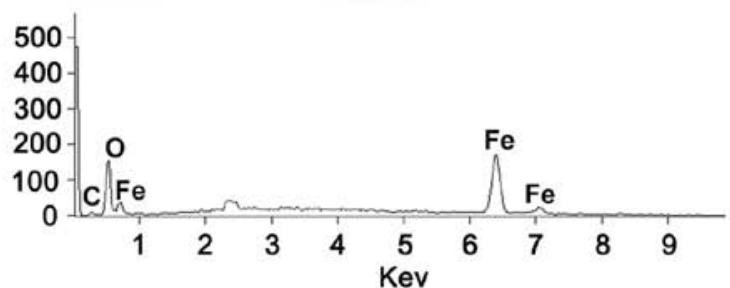

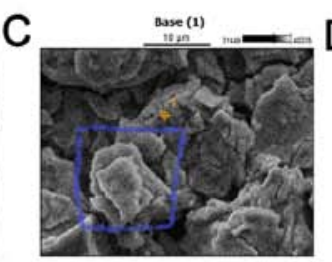
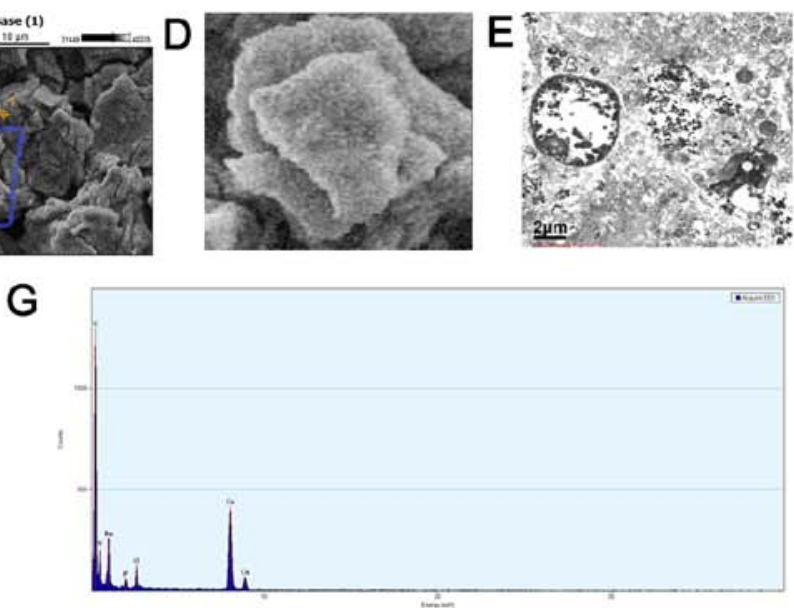
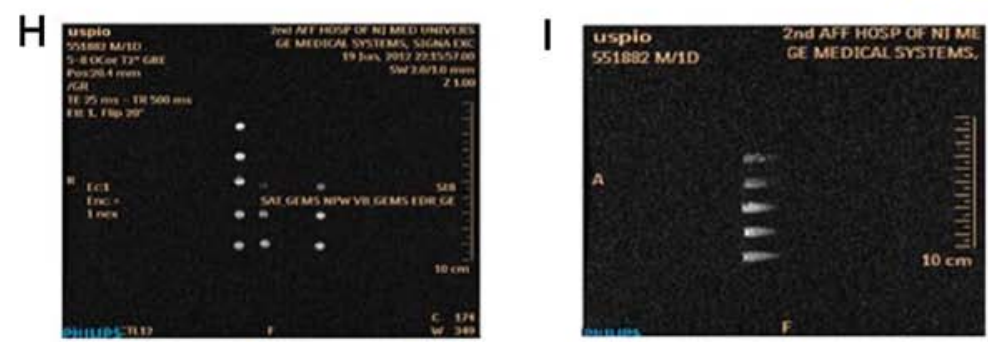

Figure 3. Morphological characteristics of EPCs. (A) Control cells without USPION labeling. Magnification, x20. (B) USPION (32 $\mu \mathrm{g} / \mathrm{ml})$ labeling are visible in labeled EPCs. Magnification, x20. (C) Local magnification image of USPION-PLL nanoparticles under a scanning electron microscope. Scale bar, $10 \mu \mathrm{m}$. (D) Magnification of the blue square in part C (magnification, $4 \mathrm{x}$ that of C). (E) USPION labeled EPCs under a scanning electron microscope. Scale bar, $2 \mu \mathrm{m}$. (F) Energy spectrum analysis of element contents in USPION. (G) Analysis of element content in EPCs labeled with USPIONs on an energy spectrometer. (H) Rightmost three samples are unlabeled EPCs. (I) Lateral scans of labeled cells by MRI. EPC, endothelial progenitor cell; USPION, ultrasmall superparamagnetic iron oxide nanoparticle; USPION-PLL, USPION-poly-1-lysine.
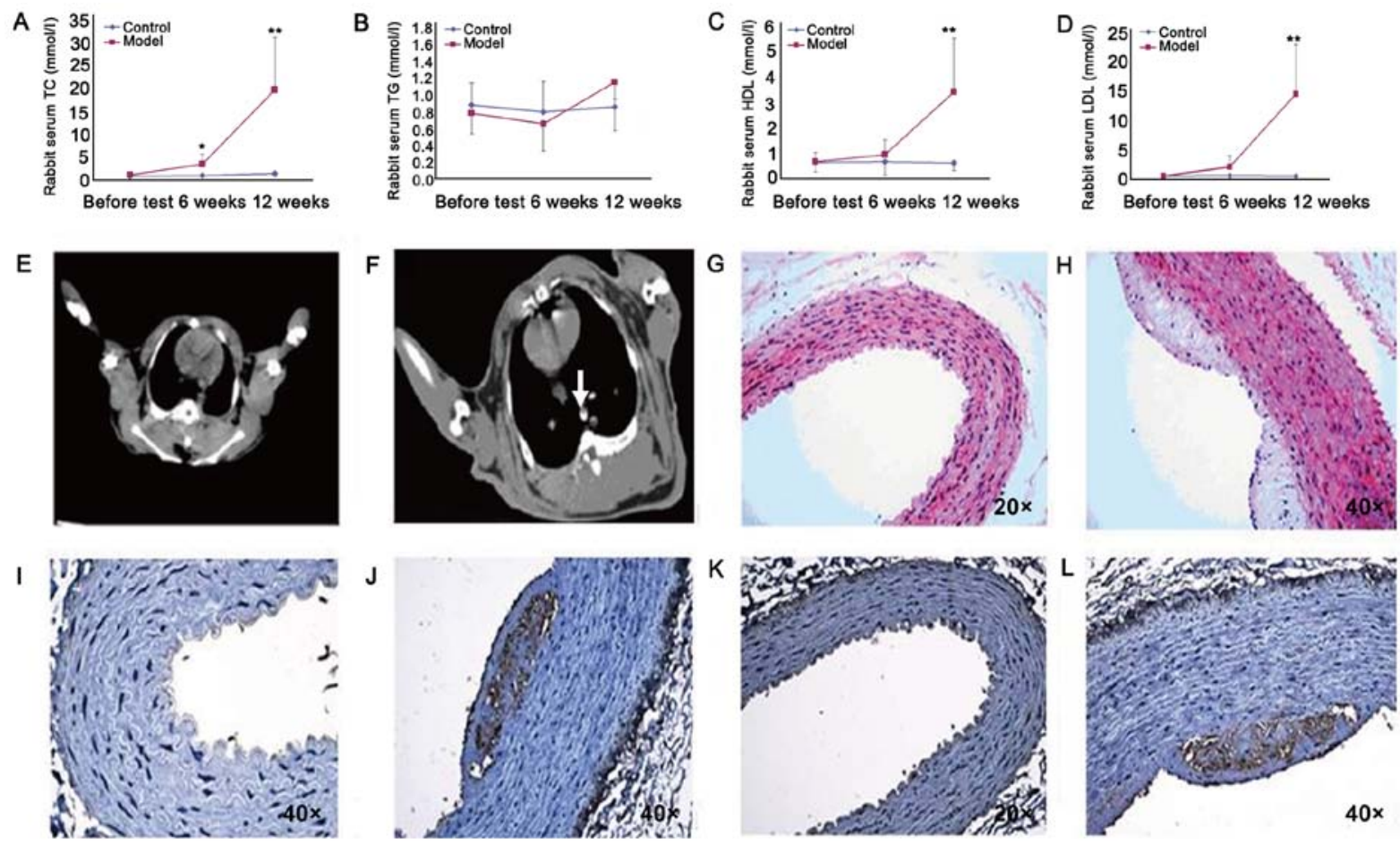

Figure 4. Trend charts of rabbit blood lipid indices in the model and control groups. Serum (A) TC, (B) TG, (C) HDL and (D) LDL levels in atherosclerosis model and control rabbits. (E) Rabbit aortic artery in the control group. (F) Atherosclerotic plaque in the rabbit aortic artery in the modeling group, as indicated by the arrow. (G) Continuous and intact intima of rabbit aortic artery in the control group. Magnification, x20. (H) Sclerotic plaque protrusions in arterial vessels in model rabbits. Magnification, x40. (I) Continuous and intact intima of rabbit aorta in the control group without MMP-2 expression. Magnification, x40. (J) Atherosclerotic plaques in model rabbits appear brown after anti-MMP-2 immunohistochemical staining. Magnification, x40. (K) Continuous and intact intima of rabbit aorta in the control group without CD280 expression. Magnification, x20. (L) Foamy brown signals were observed in atherosclerotic plaques in model rabbits after anti-CD280 immunohistochemical staining. Magnification, $\mathrm{x} 40 .{ }^{*} \mathrm{P}<0.05,{ }^{* *} \mathrm{P}<0.01$ vs. control group. TC, total cholesterol; TG, triglycerides; LDL, low-density lipoproteins; HDL, high-density lipoproteins (HDL); MMP, matrix metalloproteinases. 

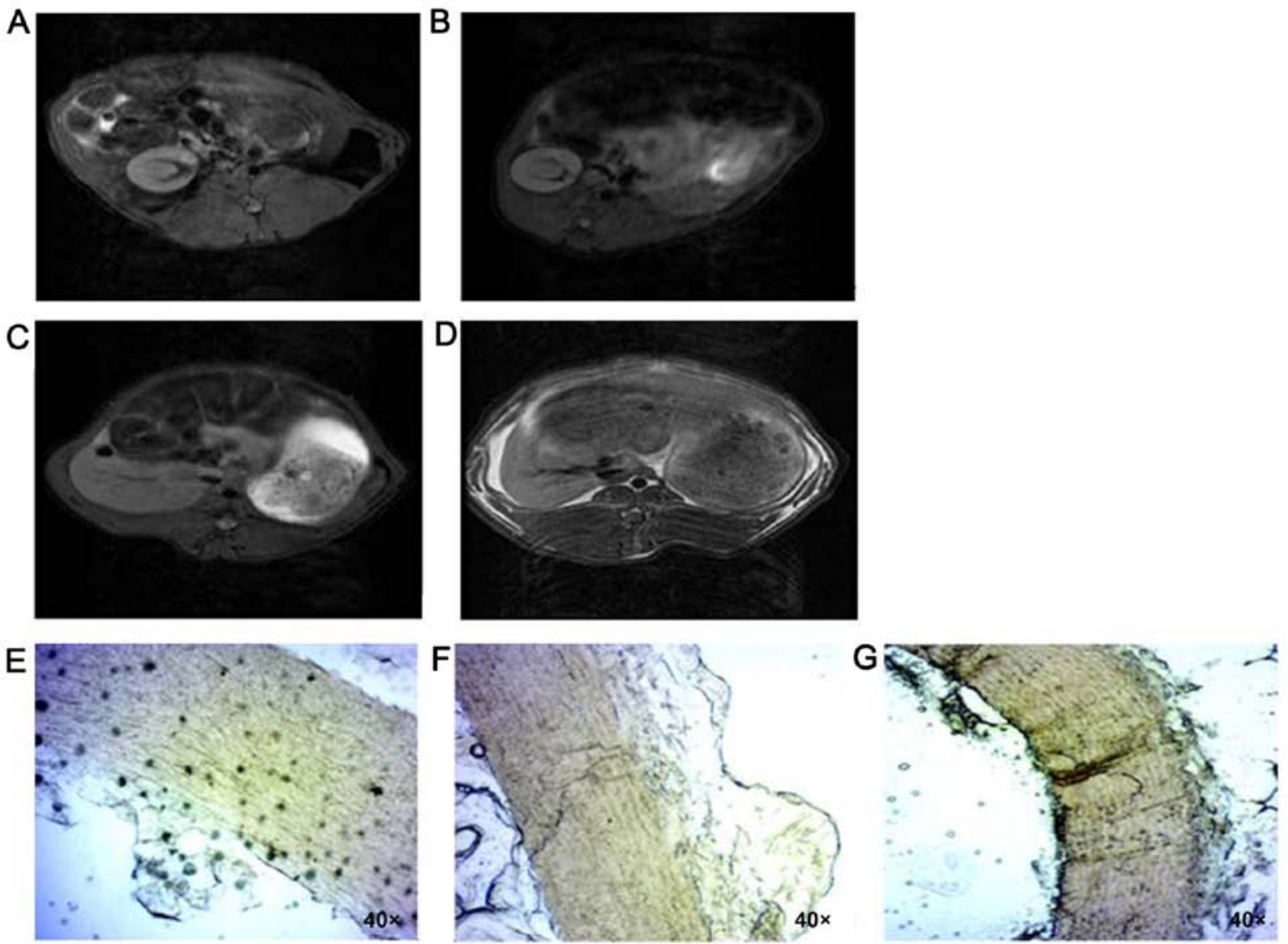

Figure 5. MRI of rabbits treated with USPION-labeled EPCs and control animals. (A) MRI of rabbits treated with USPION-labeled EPCs showed no significant changes in aortic vessels at (A) 1 day (B) 7 days and (C) 16 days after infusion. (D) MRI of rabbits in the control group. (E) Injured vessels were stained with Prussian blue 1 day after transplantation of USPION-labeled EPCs. Magnification, x40. (F) Lesion vessels were stained with Prussian blue 7 days after the transplantation of USPION-labeled EPCs. Magnification, x40. (G) Prussian blue staining of rabbit blood vessels in the control group. Magnification, x40. EPCs, endothelial progenitor cells; USPION, ultrasmall superparamagnetic iron oxide nanoparticle.

lumen, suggesting a fluent blood flow in the lumen (Fig. 5A-D). Histopathological analysis results suggested that 1 day after transplantation of labeled cells, blue-stained granules were observed in the intima of vascular lesions in model rabbits, thus indicating that the labeled EPCs were successfully implanted in the damaged vessels (Fig. 5E). Moreover, no blue-stained cells were found in pathological sections 7 days after transplantation of the labeled cells (Fig. 5F). In the control group, no blue-stained cells were observed after transplantation of unlabeled cells throughout the assay (Fig. 5G).

\section{Discussion}

In the present study, it was found that USPION-labeled EPCs could promote angiogenesis both in vitro and in vivo. Thus, the present results may facilitate the development of a novel therapeutic tools for atherosclerotic vessels.

Stem cell transplantation therapy has become a hot topic in biomedical research, but its clinical application is still limited despite breakthroughs (59-61). Currently, the greatest challenge facing EPC transplantation is how to improve in vivo survival, identify the outcomes of the transplanted cells and monitoring the effectiveness of the treatment (62). The conventional tracing method is used to performed regular observation using histopathological sections, but this method cannot dynamically monitor EPCs involved in the repair and regeneration processes of damaged vessels in real-time in vivo (62).

The development of molecular MRI technology provides new approaches for studying the therapeutic effects of EPCs transplantation by non-invasive dynamic monitoring (63). Previous studies investigating molecular imaging contrast agents based on USPION in cells are the most common $(42,43,48-50)$. It has been shown that USPION-labeled EPCs can reach the treatment target under the action of external magnetic fields and can participate in repairing damaged blood vessels (64). Moreover, USPION is highly sensitive, and has no short-term or long-term biological side effects on the labeled cells (65-67).

SPIO particles constitute an important method for evaluating plaque instability in vivo (68-70). Furthermore, EPCs labeled with SPIO particles have been widely used in the treatment of diseases, including atherosclerosis (71). This method has also been used to evaluate plaque inflammatory response in patients with carotid atherosclerosis $(43,69)$. The relatively large size of SPIO particles may result in improved uptake rate of cells $(72,73)$ and the longer half-life of blood pool USPIONs allows them to be frequently used for in vivo vessel labeling, as shown in animals and patients with several diseases, including vessel disorders $(74,75)$. In patients, the half-life of blood pool USPIONs is $>24 \mathrm{~h}$ (76), whereas that of SPIOs is 
$<6 \min$ (77). The present study investigated the potential effect of USPION-labeled EPCs homing to injured endothelium and whether local atherosclerosis could be prevented by this EPC administration. High-resolution MRI can detect plaque components in vivo, such as intra-plaque or subintimal hemorrhage, fibrous cap and lipid-rich plaque core (78-80). Thus, using USPIONs to enhance MRI could be used to show plaque inflammation in vivo $(81,82)$.

Previous studies have focused on the transplantation of EPCs for the treatment of vascular diseases $(18,25,38-40,62-64,83)$. Werner et al (84) revealed that spleen-derived endogenous or transfused progenitor cells home to the site of vascular injury, which results in enhanced reendothelialization and regeneration of endothelial cells, thus indicating a critical and novel therapeutic approach for the management of vascular injury at the early stages of atherosclerosis. Moreover, the results from this previous study (84) were consistent with those from the present study.

In addition, Ma et al (51) found that atherosclerosis is inhibited by SPIO-labeled EPCs, suggesting that these cells may play a role in the restoration of endothelial injury and atherosclerosis prevention. However, George et al (85) showed an opposite result, that the transfer of bone marrow cells or EPCs may cause increased atherosclerotic lesion size, and that EPC transfer may potentially influence plaque stability. Therefore, the discrepancy between these studies may be due to the different animal models used and different time points. In the study by George et al (85), an apolipoprotein E knockout mouse model, with atherosclerotic plaques already formed in the abdominal aorta and carotid artery, was used.

The diameter of the USPIONs used in the present study was 6-10 nm, which is smaller than that of SPIO particles (44). Encapsulated USPIONs using polylysine form electrostatic complexes to stimulate the endocytosis of EPCs, and USPIONs can enter the cytoplasm (65-67). The present results suggested that the adhesion and proliferation of EPCs were not significantly different compared with unlabeled cells, and that the biological function of these cells was maintained, which was in line with results from a previous study (23). Furthermore, the half-life of USPION in the plasma is longer than that of SPIO, it is highly biocompatible and can produce a large paramagnetism effect when subjected to a magnetic field (65-67). Moreover, USPION can form a low signal region for imaging on spin-echo and gradient-echo MRI sequences (44).

In previous imaging studies of in vitro cell populations, it has been shown that the change rate of signal intensity on T2WI is largest after cells are labeled with USPIONs $(83,86-88)$. In the present study, MRI results suggested that the change rate of signals for labeled EPCs was the most significant on T2WI. However, T2WI is associated with disadvantages such as large magnetic susceptibility artifacts on the gas-tissue interface (89). The present results also indicated that no signal change was visible in each MRI imaging sequence and that a small number of blue-stained particles were observed in the intima 1 day after transplantation, while no blue-stained particles were found at 7 and 16 days. These results may be due to the fact that damaged local intima was repaired or that there was hyperplasia of the smooth muscle cells, meaning EPCs could not remain in the intima $(90,91)$. The time of local incubation was short, the cells may have been expelled from the affected blood vessels due to the blood flow and migrated to other vascular segments (92).
Furthermore, after digestion and before transplantation, the cells remained in an in vitro environment and therefore a large number of cells died, which would affect cell adhesion to the vascular wall. In addition, the number of transplanted cells in the present study too small. Moreover, cells cannot stay locally and can undergo immune rejection (36-38).

As the number of experimental animals was small in the present study, further studies are required to assess the feasibility of diagnosing and treating atherosclerotic cardiovascular disease using the homing effect of EPCs. Currently, when using animal models, the presence of EPCs can only be confirmed by biopsy or sacrificing the animals to obtain tissues of corresponding target organs for pathological diagnosis. Thus, there is a lack of dynamic monitoring of the transplanted cells, meaning that the clinical application is limited. Therefore, there is an urgent need to use a non-invasive imaging labeling of the cells in order to trace in vivo cell distribution and to evaluate the cell retention time, differentiation and proliferation in the target organs. In addition, tracing labeled cells can lead to optimization of the window for cell transplantation, provide ideal feedback of cellular localization, and improve the understanding of the dose or number of cells required for therapeutic treatments.

In conclusion, magnetic labeling of cells with USPIONs may be an effective novel approach for monitoring the temporal and spatial migration of EPCs into vessels. Furthermore, the present results may facilitate the development of cell-based therapeutics for atherosclerosis.

\section{Acknowledgements}

Not applicable.

\section{Funding}

This work was supported by the Nanjing Municipal Health Bureau Youth Science and Technology Talents Launching Project (grant no. QYK10145).

\section{Availability of data and materials}

The datasets used and/or analyzed during the current study are available from the corresponding author on reasonable request.

\section{Authors' contributions}

$\mathrm{HW}$ and $\mathrm{KZ}$ conceived the idea, designed the experiments and supervised the study. LC, HS, TT, and LL performed the experiments, data analysis and data interpretation. JL performed the CT and MRI scans. HW and LC wrote the manuscript. All authors read and approved the final manuscript.

\section{Ethics approval and consent to participate}

The authors declare that the study was approved by The Ethics Committee of Drum Tower Hospital Affiliated to Medical College of Nanjing University.

\section{Patient consent for publication}

Not applicable. 


\section{Competing interests}

The authors declare that they have no competing interests.

\section{References}

1. Zhang Y, Koradia A, Kamato D, Popat A, Little PJ and Ta HT: Treatment of atherosclerotic plaque: Perspectives on theranostics. J Pharmacy Pharmacol: 71: 1029-1043, 2019.

2. World Health Organization (WHO), World Heart Federation, Organization WS: Global atlas on cardiovascular disease prevention and control Policies, strategies and interventions. WHO, Geneva, 2011.

3. Benjamin EJ, Blaha MJ, Chiuve SE, Cushman M, Das SR, Deo R, de Ferranti SD, Floyd J, Fornage M, Gillespie C, et al: Heart disease and stroke statistics-2017 update: A report from the american heart association. Circulation 135: e146-e603, 2017.

4. World Health Organization (WHO): Cardiovascular diseases (CVDs). WHO, Geneva, 2020. https://www.who.int/en/newsroom/fact-sheets/detail/cardiovascular-diseases-(cvds). Accessed April 6, 2020

5. Biancari F, Anttila V, Dell'Aquila AM, Airaksinen JKE and Brascia D: Control angiography for perioperative myocardial Ischemia after coronary surgery: Meta-analysis. J Cardiothorac Surg 13: 24, 2018

6. Athyros VG, Tziomalos K, Katsiki N and Mikhailidis DP: Novel data on the pathogenesis of atherosclerosis, treatment targets, and new therapeutic interventions in lipid-related cardiovascular risk factors. Curr Pharm Des 20: 6215-6219, 2014.

7. Rabelink TJ, de Boer HC and van Zonneveld AJ: Endothelial activation and circulating markers of endothelial activation in kidney disease. Nat Rev Nephrol 6: 404-414, 2010.

8. Gimbrone MA Jr and Garcia-Cardena G: Endothelial cell dysfunction and the pathobiology of atherosclerosis. Circ Res 118: 620-636, 2016.

9. Cahill PA and Redmond EM: Vascular endothelium-Gatekeeper of vessel health. Atherosclerosis 248: 97-109, 2016.

10. Theodorou $\mathrm{K}$ and Boon RA: Endothelial cell metabolism in atherosclerosis. Front Cell Dev Biol 6: 82, 2018.

11. Kwon Y, Norby FL, Jensen PN, Agarwal SK, Soliman EZ, Lip GY, Longstreth WT Jr, Alonso A, Heckbert SR and Chen LY: Association of smoking, alcohol, and obesity with cardiovascular death and ischemic stroke in atrial fibrillation: The atherosclerosis risk in communities (ARIC) study and cardiovascular health study (CHS). PLoS One 11: e0147065, 2016

12. Ruan C, Shen Y, Chen R, Wang Z, Li J and Jiang Y: Endothelial progenitor cells and atherosclerosis. Front Biosci (Landmark Ed) 18: 1194-1201, 2013.

13. Yoder MC: Human endothelial progenitor cells. Cold Spring Harb Perspect Med 2: a006692, 2012.

14. Peters EB: Endothelial progenitor cells for the vascularization of engineered tissues. Tissue Eng Part B Rev 24: 1-24, 2018.

15. Li DW, Liu ZQ, Wei J, Liu Y and Hu LS: Contribution of endothelial progenitor cells to neovascularization (Review). Int J Mol Med 30: 1000-1006, 2012.

16. Mudyanadzo TA: Endothelial progenitor cells and cardiovascular correlates. Cureus 10: e3342, 2018.

17. Grisar JC, Haddad F, Gomari FA and Wu JC: Endothelial progenitor cells in cardiovascular disease and chronic inflammation: From biomarker to therapeutic agent. Biomark Med 5: 731-744, 2011.

18. Dzau VJ, Gnecchi M, Pachori AS, Morello F and Melo LG: Therapeutic potential of endothelial progenitor cells in cardiovascular diseases. Hypertension 46: 7-18, 2005.

19. Qiu Y, Zhang C, Zhang G and Tao J: Endothelial progenitor cells in cardiovascular diseases. Aging Med 1: 204-208, 2018.

20. Gao X, Chen W, Liang Z and Chen L: Autotransplantation of circulating endothelial progenitor cells protects against lipopolysaccharide-induced acute lung injury in rabbit. Int Immunopharmacol 11: 1584-1590, 2011.

21. Chen ZZ, Jiang XD, Zhang LL, Shang JH, Du MX, Xu G and Xu RX: Beneficial effect of autologous transplantation of bone marrow stromal cells and endothelial progenitor cells on cerebral ischemia in rabbits. Neurosci Lett 445: 36-41, 2008.

22. Chen B, Bo CJ, Jia RP, Liu H, Wu R, Wu J, Ge YZ and Teng GJ The renoprotective effect of bone marrow-derived endothelial progenitor cell transplantation on acute ischemia-reperfusion injury in rats. Transplant Pro 45: 2034-2039, 2013
23. Li ZF, Fang XG, Yang PF, Huang QH, Zhao WY, Liang C, Zhao R and Liu JM: Endothelial progenitor cells contribute to neointima formation in rabbit elastase-induced aneurysm after flow diverter treatment. CNS Neurosci Ther 19: 352-357, 2013.

24. Cui K, Ma X, Yu L, Jiang C, Fu C, Fu X, Yu X, Huang Y, Hou S, Si C, et al: Autologous bone marrow mononuclear cell transplantation delays progression of carotid atherosclerosis in rabbits. Mol Neurobiol 53: 4387-4396, 2016.

25. Zhang M, Malik AB and Rehman J: Endothelial progenitor cells and vascular repair. Curr Opin Hematol 21: 224-228, 2014.

26. Rajendran $P$, Rengarajan $T$, Thangavel J, Nishigaki $Y$, Sakthisekaran D, Sethi G and Nishigaki I: The vascular endothelium and human diseases. Int J Biol Sci 9: 1057-1069, 2013.

27. Kruger-Genge A, Blocki A, Franke RP and Jung F: Vascular endothelial cell biology: An update. Int J Mol Sci 20: 4411, 2019

28. Asahara T, Murohara T, Sullivan A, Silver M, van der Zee R, Li T, Witzenbichler B, Schatteman G and Isner JM: Isolation of putative progenitor endothelial cells for angiogenesis. Science 275 964-967, 1997.

29. Pirro M, Stingeni L, Vaudo G, Mannarino MR, Ministrini S, Vonella M, Hansel K, Bagaglia F, Alaeddin A, Lisi P and Mannarino E: Systemic inflammation and imbalance between endothelial injury and repair in patients with psoriasis are associated with preclinical atherosclerosis. Eur J Prev Cardiol 22: 1027-1035, 2015

30. Groleau J, Dussault S, Haddad P, Turgeon J, Menard C, Chan JS and Rivard A: Essential role of copper-zinc superoxide dismutase for ischemia-induced neovascularization via modulation of bone marrow-derived endothelial progenitor cells. Arterioscler Thromb Vasc Biol 30: 2173-2181, 2010.

31. Ankeny RF, Ankeny CJ, Nerem RM and Jo H: Maturing EPCs into endothelial cells: May the force be with the EPCs: Focus on 'Fluid shear stress induces differentiation of circulating phenotype endothelial progenitor cells'. Am J Physiol Cell Physiol 303: C589-C591, 2012.

32. Psaltis PJ and Simari RD: Vascular wall progenitor cells in health and disease. Circ Res 116: 1392-1412, 2015.

33. Zhang X, Mao H, Chen JY, Wen S, Li D, Ye M and Lv Z: Increased expression of microRNA-221 inhibits PAK1 in endothelial progenitor cells and impairs its function via c-Raf/MEK/ERK pathway. Biochem Biophys Res Commun 431: 404-408, 2013.

34. Aicher A, Brenner W, Zuhayra M, Badorff C, Massoudi S, Assmus B, Eckey T, Henze E, Zeiher AM and Dimmeler S: Assessment of the tissue distribution of transplanted human endothelial progenitor cells by radioactive labeling. Circulation 107 2134-2139, 2003

35. Asahara T, Kawamoto A and Masuda H: Concise review: Circulating endothelial progenitor cells for vascular medicine. Stem Cells 29: 1650-1655, 2011.

36. Nuzzolo ER, Capodimonti S, Martini M, Iachininoto MG, Bianchi M, Cocomazzi A, Zini G, Leone G, Larocca LM and Teofili L: Adult and cord blood endothelial progenitor cells have different gene expression profiles and immunogenic potential. Blood Transfus 12 (Suppl 1): S367-S374, 2014

37. Souidi N, Stolk M, Rudeck J, Strunk D, Schallmoser K, Volk HD and Seifert M: Stromal cells act as guardians for endothelial progenitors by reducing their immunogenicity after co-transplantation. Stem Cells 35: 1233-1245, 2017.

38. Ladhoff J, Fleischer B, Hara Y, Volk HD and Seifert M: Immune privilege of endothelial cells differentiated from endothelial progenitor cells. Cardiovasc Res 88: 121-129, 2010.

39. Fang J, Guo Y, Tan S, Li Z, Xie H, Chen P, Wang K, He Z, He P, $\mathrm{Ke} \mathrm{Y}$, et al: Autologous endothelial progenitor cells transplantation for acute ischemic stroke: A 4-Year Follow-Up Study. Stem Cells Transl Med 8: 14-21, 2019.

40. Fan CL, Gao PJ, Che ZQ, Liu JJ, Wei J and Zhu DL: Therapeutic neovascularization by autologous transplantation with expanded endothelial progenitor cells from peripheral blood into ischemic hind limbs. Acta Pharmacol Sin 26: 1069-1075, 2005.

41. Yin Y, Liu H, Wang F, Li L, Deng M, Huang L and Zhao X: Transplantation of cryopreserved human umbilical cord blood-derived endothelial progenitor cells induces recovery of carotid artery injury in nude rats. Stem Cell Res Ther 6: 37, 2015.

42. Suzuki M, Bachelet-Violette L, Rouzet F, Beilvert A, Autret G, Maire M, Menager C, Louedec L, Choqueux C, Saboural P, et al: Ultrasmall superparamagnetic iron oxide nanoparticles coated with fucoidan for molecular MRI of intraluminal thrombus. Nanomedicine (Lond) 10: 73-87, 2015. 
43. Usman A, Sadat U, Patterson AJ, Tang TY, Varty K, Boyle JR, Armon MP, Hayes PD, Graves MJ and Gillard JH: Use of ultrasmall superparamagnetic iron oxide particles for imaging carotid atherosclerosis. Nanomedicine (Lond) 10: 3077-3087, 2015.

44. Zhao X, Zhao H, Chen Z and Lan M: Ultrasmall superparamagnetic iron oxide nanoparticles for magnetic resonance imaging contrast agent. J Nanosci Nanotechnol 14: 210-220, 2014.

45. Fang Y, Wu Y, Liao P, Chen Z, Chen H, Yu J, Liu Y, Li S, Su E, $\mathrm{He} \mathrm{N}$, et al: Design and application of a high-throughput sample processing module based on magnetic beads. Nanosci Nanotech Lett 10: 320-328, 2018.

46. Chen Z, Wu Y, Kang M, He N, Wan S, Su E and Lijun W: Research on automated nucleic acid extraction instrument based on magnetic nanoparticles separation. Nanosci Nanotech Lett 10: 60-68, 2018

47. Liu H, Dong H, Chen Z, Lin L, Chen H, Li S and Deng Y: Magnetic nanoparticles enhanced microarray detection of multiple foodborne pathogens. J Biomed Nanotech 13: 1333-1343, 2017.

48. Wang X, Zhang T, Zhao X, Guan Z, Wang Z, Zhu Z, Xie Q, Wang $J$ and Niu B: Quantification of folate metabolites in serum using ultraperformance liquid chromatography tandem mass spectrometry. J Chromatogr B Analyt Technol Biomed Life Sci 962: 9-13, 2014

49. Ittrich H, Peldschus K, Raabe N, Kaul M and Adam G: Superparamagnetic iron oxide nanoparticles in biomedicine: Applications and developments in diagnostics and therapy. Rofo 185: 1149-1166, 2013.

50. Guo L, Chen H, He N and Deng Y: Effects of surface modifications on the physicochemical properties of iron oxide nanoparticles and their performance as anticancer drug carriers. Chin Chem Lett 29: 1829-1833, 2018.

51. Ma ZL, Mai XL, Sun JH, Ju SH, Yang X, Ni Y and Teng GJ: Inhibited atherosclerotic plaque formation by local administration of magnetically labeled endothelial progenitor cells (EPCs) in a rabbit model. Atherosclerosis 205: 80-86, 2009.

52. Lipman NS, Marini RP and Erdman SE: A comparison of ketamine/xylazine and ketamine/xylazine/acepromazine anesthesia in the rabbit. Lab Anim Sci 40: 395-398, 1990.

53. Marini RP, Li X, Harpster NK and Dangler C: Cardiovascular pathology possibly associated with ketamine/xylazine anesthesia in Dutch belted rabbits. Lab Anim Sci 49: 153-160, 1999.

54. Baneux PJ, Garner D, McIntyre HB and Holshuh HJ: Euthanasia of rabbits by intravenous administration of ketamine. J Am Vet Med Assoc 189: 1038-1039, 1986.

55. Cicero L, Fazzotta S, Palumbo VD, Cassata G and Lo Monte AI Anesthesia protocols in laboratory animals used for scientific purposes. Acta Biomed 89: 337-342, 2018.

56. Huang YH, Xu Q, Shen T, Li JK, Sheng JY and Shi HJ Prevention of in-stent restenosis with endothelial progenitor cell (EPC) capture stent placement combined with regional EPC transplantation: An atherosclerotic rabbit model. Cardiol J 26: 283-291, 2019.

57. Patel J, Seppanen EJ, Rodero MP, Wong HY, Donovan P, Neufeld Z, Fisk NM, Francois M and Khosrotehrani K: Functional definition of progenitors versus mature endothelial cells reveals key SoxF-dependent differentiation process. Circulation 135 786-805, 2017.

58. Flores-Nascimento MC, Alessio AM, de Andrade Orsi FL and Annichino-Bizzacchi JM: CD144, CD146 and VEGFR-2 properly identify circulating endothelial cell. Rev Bras Hematol Hemoter 37: 98-102, 2015.

59. Wei L, Wei ZZ, Jiang MQ, Mohamad O and Yu SP: Stem cell transplantation therapy for multifaceted therapeutic benefits after stroke. Prog Neurobiol 157: 49-78, 2017.

60. Kamelska-Sadowska AM, Wojtkiewicz J and Kowalski IM: Review of the current knowledge on the role of stem cell transplantation in neurorehabilitation. Biomed Res Int 2019: 3290894, 2019.

61. Cho J, D'Antuono M, Glicksman M, Wang J and Jonklaas J: A review of clinical trials: Mesenchymal stem cell transplant therapy in type 1 and type 2 diabetes mellitus. Am J Stem Cells 7: 82-93, 2018

62. Chong MS, Ng WK and Chan JK: Concise review: Endothelial progenitor cells in regenerative medicine: Applications and challenges. Stem Cells Transl Med 5: 530-538, 2016.

63. Peng X, Li C, Bai Y, Wang X, Zhang Y, An Y, Teng GJ and Ju S: Noninvasive evaluation of the migration effect of transplanted endothelial progenitor cells in ischemic muscle using a multimodal imaging agent. Int J Nanomedicine 13: 1819-1829, 2018.
64. Zhang BF, Jiang H, Chen J,Hu Q, Yang S and Liu XP: Silica-coated magnetic nanoparticles labeled endothelial progenitor cells alleviate ischemic myocardial injury and improve long-term cardiac function with magnetic field guidance in rats with myocardial infarction. J Cell Physiol 234: 18544-18559, 2019.

65. Leung K: Ultrasmall superparamagnetic iron oxide-LeuIle-Lys-Lys-Pro-Phe. Molecular Imaging and Contrast Agent Database (MICAD), Bethesda, MD, 2004

66. Leung K: Ultrasmall superparamagnetic iron oxide-cyclo(Cys -Asn-Asn-Ser-Lys-Ser-His-Thr-Cys). Molecular Imaging and Contrast Agent Database (MICAD), Bethesda, MD, 2004.

67. Leung K: Ultrasmall superparamagnetic iron oxide nanoparticles conjugated with Ile-Pro-Leu-Pro-Phe-Tyr-Asn. Molecular Imaging and Contrast Agent Database (MICAD), Bethesda, MD, 2004.

68. Zhou Q, Yang KR, Gao P, Chen WL, Yang DY, Liang MJ and Zhu L: An experimental study on MR imaging of atherosclerotic plaque with SPIO marked endothelial cells in a rabbit model. J Magn Reson Imaging 34: 1325-1332, 2011.

69. Tang TY, Muller KH, Graves MJ, Li ZY, Walsh SR, Young V, Sadat U, Howarth SP and Gillard JH: Iron oxide particles for atheroma imaging. Arterioscler Thromb Vasc Biol 29: 1001-1008, 2009.

70. Alam SR, Stirrat C, Richards J, Mirsadraee S, Semple SI, Tse G, Henriksen P and Newby DE: Vascular and plaque imaging with ultrasmall superparamagnetic particles of iron oxide. J Cardiovasc Magn Reson 17: 83, 2015.

71. Moon SH, Kim SM, Park SJ, Kim H, Bae D, Choi YS and Chung HM: Development of a xeno-free autologous culture system for endothelial progenitor cells derived from human umbilical cord blood. PLoS One 8: e75224, 2013.

72. Daldrup-Link HE, Rudelius M, Oostendorp RA, Settles M, Piontek G, Metz S, Rosenbrock H, Keller U, Heinzmann U, Rummeny EJ, et al: Targeting of hematopoietic progenitor cells with MR contrast agents. Radiology 228: 760-767, 2003.

73. Matuszewski L, Persigehl T, Wall A, Schwindt W, Tombach B Fobker M, Poremba C, Ebert W, Heindel W and Bremer C: Cell tagging with clinically approved iron oxides: Feasibility and effect of lipofection, particle size, and surface coating on labeling efficiency. Radiology 235: 155-161, 2005.

74. Rausch M, Sauter A, Frohlich J, Neubacher U, Radu EW and Rudin M: Dynamic patterns of USPIO enhancement can be observed in macrophages after ischemic brain damage. Magn Reson Med 46: 1018-1022, 2001.

75. Saleh A, Schroeter M, Jonkmanns C, Hartung HP, Modder U and Jander S: In vivo MRI of brain inflammation in human ischaemic stroke. Brain 127: 1670-1677, 2004.

76. McLachlan SJ, Morris MR, Lucas MA, Fisco RA, Eakins MN, Fowler DR, Scheetz RB and Olukotun AY: Phase I clinical evaluation of a new iron oxide MR contrast agent. J Magn Reson Imaging 4: 301-307, 1994.

77. Weissleder R, Stark DD, Engelstad BL, Bacon BR, Compton CC, White DL, Jacobs P and Lewis J: Superparamagnetic iron oxide: Pharmacokinetics and toxicity. AJR Am J Roentgenol 152: 167-173, 1989.

78. Ryu CW, Kwak HS, Jahng GH and Lee HN: High-resolution MRI of intracranial atherosclerotic disease. Neurointervention 9: 9-20, 2014

79. Kerwin WS and Canton G: Advanced techniques for MRI of atherosclerotic plaque. Top Magn Reson Imaging 20: 217-225, 2009.

80. Wang E, Shao S, Li S, Yan P, Xiang Y, Wang X, Li J, Wang G, Sun Q and Du Y: A High-resolution MRI study of the relationship between plaque enhancement and ischemic stroke events in patients with intracranial atherosclerotic stenosis. Front Neurol 9: 1154, 2018.

81. Smits LP, Tiessens F, Zheng KH, Stroes ES, Nederveen AJ and Coolen BF: Evaluation of ultrasmall superparamagnetic iron-oxide (USPIO) enhanced MRI with ferumoxytol to quantify arterial wall inflammation. Atherosclerosis 263: 211-218, 2017.

82. Kaneko C, Nitta N, Tsuchiya K, Watanabe S, Nitta-Seko A, Ohta S, Otani H, Sonoda A, Murata K and Shiomi M: MRI study of atherosclerotic plaque progression using ultrasmall superparamagnetic iron oxide in Watanabe heritable hyperlipidemic rabbits. Br J Radiol 88: 20150167, 2015.

83. Yao Y, Li Y, Ma G, Liu N, Ju S, Jin J, Chen Z, Shen C and Teng G: In vivo magnetic resonance imaging of injected endothelial progenitor cells after myocardial infarction in rats. Mol Imaging Biol 13: 303-313, 2011. 
84. Werner N, Junk S, Laufs U, Link A, Walenta K, Bohm M and Nickenig G: Intravenous transfusion of endothelial progenitor cells reduces neointima formation after vascular injury. Circ Res 93: e17-e24, 2003.

85. George J, Afek A, Abashidze A, Shmilovich H, Deutsch V, Kopolovich J, Kopolovich J, Miller H and Keren G: Transfer of endothelial progenitor and bone marrow cells influences atherosclerotic plaque size and composition in apolipoprotein $\mathrm{E}$ knockout mice. Arterioscler Thromb Vasc Biol 25: 2636-2641, 2005.

86. Mergo PJ, Engelken JD, Helmberger T and Ros PR: MRI in focal liver disease: A comparison of small and ultra-small superparamagnetic iron oxide as hepatic contrast agents. J Magn Reson Imaging 8: 1073-1078, 1998.

87. Czarniecki M, Pesapane F, Wood BJ, Choyke PL and Turkbey B: Ultra-small superparamagnetic iron oxide contrast agents for lymph node staging of high-risk prostate cancer. Transl Androl Urol 7 (Suppl 4): S453-S461, 2018.

88. Matuszewski L, Tombach B, Heindel W and Bremer C: Molecular and parametric imaging with iron oxides. Radiologe 47: 34-42, 2007 (In German).
89. Engels RRM, Israel B, Padhani AR and Barentsz JO: Multiparametric magnetic resonance imaging for the detection of clinically significant prostate cancer: What urologists need to know. Part 1: Acquisition. Eur Urol 77: 457-468, 2020.

90. Yang JX, Pan YY, Wang XX, Qiu YG and Mao W: Endothelial progenitor cells in age-related vascular remodeling. Cell Transplant 27: 786-795, 2018.

91. Simard T, Jung RG, Motazedian P, Di Santo P, Ramirez FD, Russo JJ, Labinaz A, Yousef A, Anantharam B, Pourdjabbar A and Hibbert B: Progenitor cells for arterial repair: Incremental advancements towards therapeutic reality. Stem Cells Int 2017: 8270498, 2017.

92. Lin Y, Weisdorf DJ, Solovey A and Hebbel RP: Origins of circulating endothelial cells and endothelial outgrowth from blood. J Clin Invest 105: 71-77, 2000.

(7) (9) This work is licensed under a Creative Commons Attribution-NonCommercial-NoDerivatives 4.0 International (CC BY-NC-ND 4.0) License. 